\title{
Collecting Online Memetic Cultures: how tho
}

\author{
Arran John Rees
}

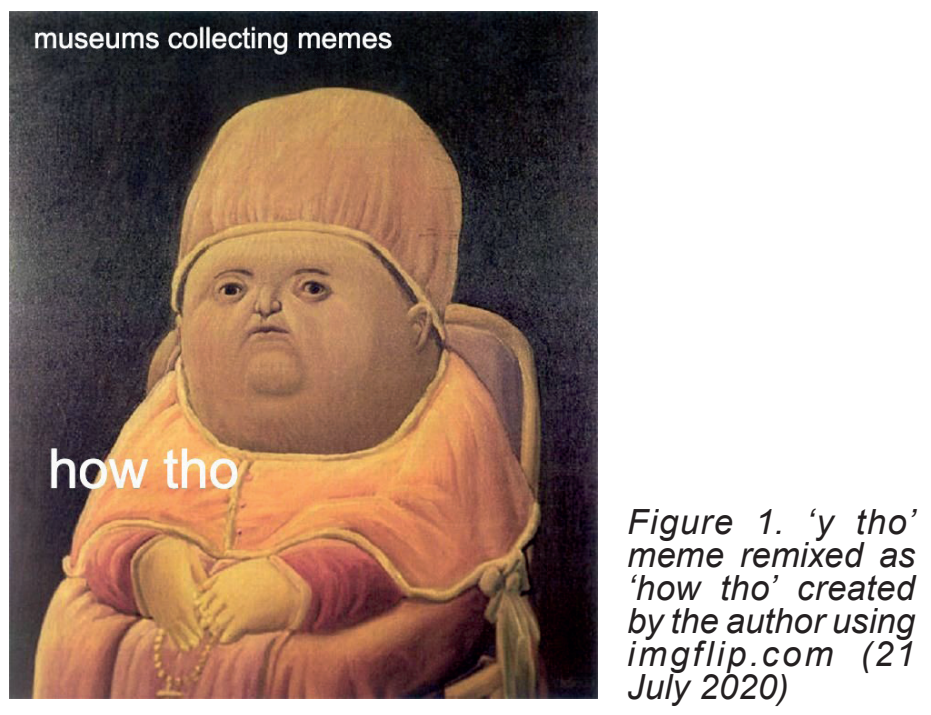

Abstract

Using insights gained from reflexive dyadic interviews undertaken as part of ongoing action research, this article positions memes as new and emerging objects of digital cultural heritage and begins to work through the implications of collecting them on museum acquisition practices. The article explores how Stockholm County Museum has collected memes as part of their digital photography collecting activities and draws out the challenges that a meme's materiality and remix qualities present to provenance, Copyright and ownership. The article concludes that acquisition standards should be remixed to be more appropriate for the cultural contexts that memes sit within and offers some preliminary suggestions on the how tho of collecting. A key feature of those suggestions is my proposal that being more open to alternative approaches to ownership may be more appropriate for these new and emerging object types.

Key words: Memes, Remix, digital collecting, digital heritage, social media, acquisition, collections management

\section{Introduction}

Internet memes are primarily visual and textual objects created, shared, edited and reshared through a variety of online platforms, networks and communities. Memes rely on participation by reappropriation, created collectively and transformed by large numbers of cultural participants (Milner 2016: 2). They are increasingly recognised as some of the most fundamental aspects of contemporary digital culture (Shifman 2014: 4). The most common form of meme, and the ones considered in this paper, are image based and overlaid with text. However, memes 
can also be video and performance based (Milner 2016: 18), with social media platforms like TikTok currently facilitating a flourishing of video and performance style memes (Zulli and Zulli 2020: 5).

Media scholar Anastasia Denisova explains how the meme's role in contemporary society can be understood as either 'fast-food media' - flashy and tempting with a low nutritional value - the sort shared between friends as inside jokes; or they can be 'mindbombs' - tactical and striking interventions into mainstream discourses (Denisova 2019: 33-5). As an individual, I acknowledge and enjoy them as both, but in this article, I use them as miniature mindbombs - as provocations to mainstream museum acquisition processes for objects from online remix cultures. As objects of digital culture, memes sit awkwardly within established property regimes, obfuscating attempts to establish clear provenance, and rejecting the traditional notions of ownership that form a central pillar of established museum acquisition processes.

Drawing on insights from one of my reflexive dyadic interviews undertaken with colleagues at Stockholm County Museum as part of collaborative action research with the Collecting Social Photo project, ${ }^{1}$ and reflections on my time as a collections manager in the sector, I draw out the challenges that collecting memes presents to acquisition processes. The how tho of this article focuses particularly on provenance, Copyright and ownership as three key elements of acquisition that were surfaced through my discussions with Stockholm County Museum. The article proposes that acquisition processes are remixed to become more attentive to the contexts from which objects are being collected. In the case of remix cultures, where memes are created and shared, being open to practices of shared ownership is presented as more appropriate for these new and emerging object types.

The article begins by contextualizing memes and situating them as new and emerging object types. However, the development of an in-depth argument as to why individual museums should collect memes is not the aim of this article. I am writing from the perspective of a collections manager who does not decide what objects are collected but is responsible for ensuring the collecting method is in place and the right processes are followed. Therefore, the focus of this article is an exploration of the potential implications of collecting memes, and preliminary suggestions on how the remixing of acquisition practices might enable museums to collect memes. The term 'remix' is used throughout this article in reference to the act of interacting with or using pre-existing materials to create something new (Navas et al. 2015: 1).

There is a growing recognition of the potential of remix studies as a way of considering change, and it is used here to consider how to adapt existing museum processes by using a mixture of processes that have been shown to work in other contexts. The adoption of the term 'remix' in this paper also refers to the digital environment in which memes are created. Lawrence Lessig explains how contemporary remix culture has developed through the flourishing of digital technologies, and in particular the Internet, web 2.0 and platforms designed around sharing digital content (Lessig 2008). In doing so, he describes remix culture as the shift from the Read Only culture, dominant in the twentieth century, to a Read Write culture. In that Read Write culture, we read, edit, and re-appropriate cultural content and create something new (Lessig 2008: 28). That new outcome is the remix.

My primary mode of research is action research. The world is not self-explanatory, and museums and their particular ways of doing things are even less so. How and why things are done in certain ways is a product of tradition, experience, and perception (Bradbury 2015: 377). In order to understand this, I research and generate knowledge through my own actions and interactions with people, cultures, and literatures; by undertaking a range of experiments, engaging in conversations and by observing. This article uses insights gained through reflections on my work in the sector over the past decade, and reflexive dyadic interviews undertaken as part of my work with colleagues in the Collecting Social Photo project. Reflexive dyadic interviews are often used in autoethnographic work where the mode of interviewing focuses on the interviewee, but also acknowledges the words, thoughts and feelings of the interviewer. This type of interview does not disregard the researchers' own experience and knowledge on the subject (Ellis et al. 2011: para 3) - a mode of working that I find allows interviews to feel less static, develop in unexpected ways, and flow more as a professional conversation between peers. 
You may have noticed my use of a meme to open this article. In Denisova's description of memes as mindbombs she refers to them as 'visually striking persuasive symbols' with potential to condense complex issues (Denisova 2019: 34). The idea of memes as 'discursive weapons' comes originally from the Dutch design studio Metahaven, which suggested memes as useful ammunition in power struggles (Metahaven 2013). Denisova's work extends their concept by identifying the making and sharing of memes as the 'principle, practice and product of narrative intervention in hegemonic agenda' (Denisova 2019: 34-5). Inspired by this idea of memes as a tool in unsettling hegemonic ideas, the article uses memes in two ways. First and foremost, they are used as symbolic objects that perturb the museum's reliance on traditional materiality and problematize the acquisition of digital material using existing museum standards. However, I also use memes as a form of communication throughout. I play with, reappropriate and remix a variety of memes in this article as interventions to unsettle, to highlight absurdities and to illustrate my arguments in creative and subject appropriate ways.

As an action researcher, I am keen that I practice what I preach, and this is why in arguing that memes are valid objects to be collected by museums, I also want to make the point that they are valid tools in communicating ideas, be it on a family WhatsApp group, on Twitter, or in academic journals. I am aware that as a reader, you might think of my use of memes as a gimmick. Sianne Ngai unpacks the associations with the term gimmick, noting that calling something a gimmick is often a distancing judgement, a way to publicly proclaim that you are unconvinced by something despite others indicating their attraction to it (Ngai 2017: 471). However, Ngai follows up that, in calling something a gimmick, you are indirectly acknowledging its power to enchant - even if you do not find yourself susceptible (Ngai 2017: 467). So, if you have decided that my use of memes is a gimmick, it is also possible that in doing so you are confirming their potential power. This is a power that I am aware of and keen to use.

\section{Memes as museum objects}

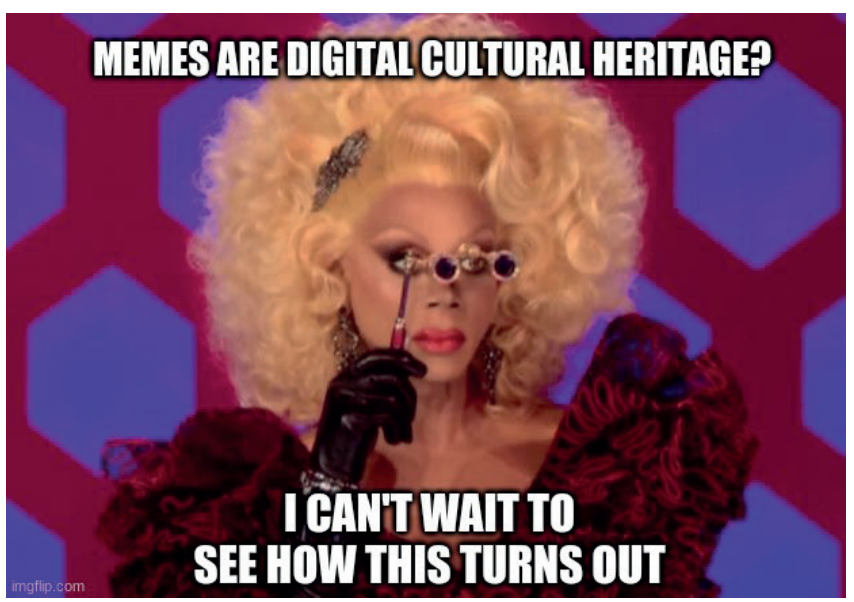

Figure 2. 'I can't wait to see how this turns out' meme created by the author using imgflip.com (3 January 2020)
Growing up in the 1990s and early 2000 s I am aware that much of the digital culture that helped shape me as the person I am today is already lost. This is true despite web archiving being a wellestablished practice. The Internet Archive as well as National Libraries and archive services around the world have been building large collections of preserved websites (Brügger and Schroeder 2017: 7), and projects liked Documenting the Now have made substantial leaps forward through developing tools and ethical practices around the archiving of social media content. ${ }^{2}$ In amongst this activity to preserve the web and its content, museums have been slow to recognise and begin valuing online and born-digital materials as significant and worth collecting.

In noting this, I do not wish to suggest that museums have not undertaken any work in this area. Internet art has been collected in art galleries such as The Whitney and Tate for a number of years (Paul 2008, 2016; Graham 2014) and the New Museum in New York has been affiliated with digital art organization Rhizome since $2003 .{ }^{3} \mathrm{~A}$ handful of museums have also begun to address how to collect social media content, with interesting examples from the Museum of London and the Victoria and Albert Museum (V\&A). However, museums are yet 
to really start engaging with collecting born-digital materials from online environments as part of ongoing practice rather than one-off projects. Therefore, in the spirit of re-orientating the value of born-digital online materials in museums, I want to look more closely at memes. As explained, a full work-up of why different types of museums should collect memes is beyond the scope of this paper. However, in exploring the history as well as the contemporary significance of memes and memetic culture, this article seeks to make some preliminary suggestions as to why museums should consider them as new and emerging objects of digital culture.

Memes have become integrated into a wide range of social practices and reflect society's increasingly graphical modes of communication and self-expression. The content of memes ranges from humorous commentary on day-to-day life to more subversive appropriations of cultural imagery by political extremists. Taking a well-documented example, Pepe the Frog, we can observe how a meme originating from a comic series and initially named the Feels Good Man meme was re-appropriated by alt-right groups (Figure 3). During the 2016 US Presidential Elections Pepe began to be used by supporters of Donald Trump to propagate white supremacism. This became so widespread that Hillary Clinton released a statement about the use of the meme. ${ }^{4}$ Denisova urges us to reflect on the fact that the meme became so powerful as a symbol that a US Presidential Candidate felt the need to release a formal statement about it (Denisova 2019: 27). This pattern of use and re-appropriation is not unique to Pepe - memes have become much more than funny pictures; they have, and will continue to play a large part in some of the defining events of the twenty-first century (Shifman 2014: 6). The term meme was originally coined by Richard Dawkins and proposed as a unit of cultural transmission or imitation. Dawkins argued that 'just as genes propagate themselves in the gene pool by leaping from body to body... so memes propagate themselves... by leaping from brain to brain via a process which, in the broad sense, can be called imitation' (Dawkins 2006: 192). There is no real clarity on when this concept of a meme shifted towards our current understanding of Internet memes as remixed manifestations of visual culture, but media scholars Victoria Esteves and Graham Meikle claim that the term meme in the context of remixing images and text started being recognised more widely as part of the Occupy Wall Street events of 2011 (Esteves and Meikle 2015: 563).

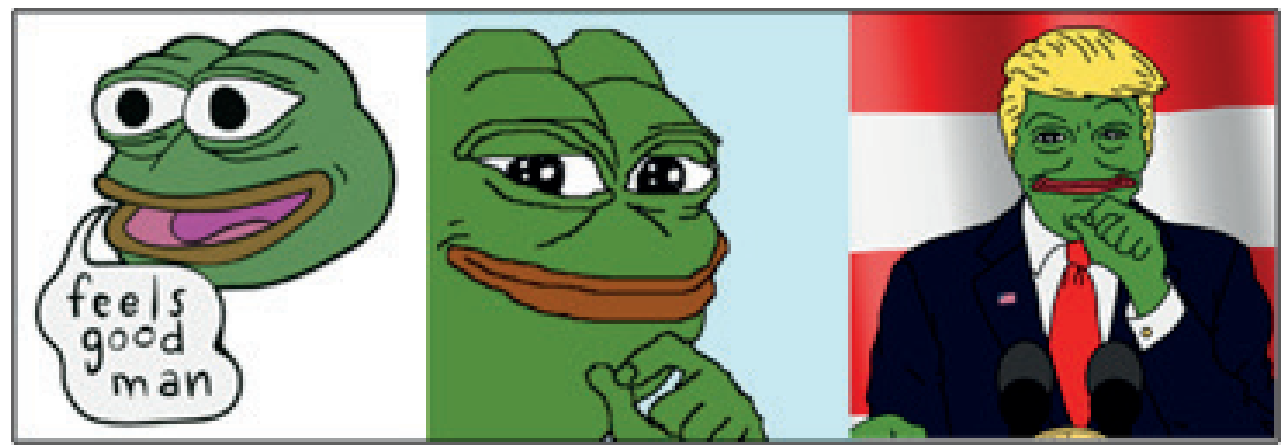

Figure 3. The evolution of the Pepe the Frog meme - images taken from https:// knowyourmeme.com/memes/pepe-the-frog, accessed 6 August 2020.

Recent scholarship has seen memes discussed from a variety of different perspectives, but most consistently as folkloric tradition. Whitney Phillips and Ryan Milner classify memes as 'folkloric expression' - or more simply, the stuff people share (Phillips and Milner 2017: 37). They argue that at its core, folkloric expression shapes the people we are, our humour, values and basic understanding of the world (Phillips and Milner 2017: 21-4). Others, like Dragan Espenchied and Olia Lialina, have worked to explicitly define computer mediated forms of folklore as Digital Folklore, defining it as the 'customs, traditions and elements of visual, textual and audio culture that emerged from users' engagements with personal computer applications during the last decade of the 20th and the first decade of the 21st century' (Espenschied and Lialina 2009: 9-10) - this, of course, includes memes in all their 
variety of form and genre. Later work by Gabriele de Seta categorizes the ways in which Digital Folklore has been researched and theorized within scholarship, specifying memes and memetics as one of the key areas of study (de Seta 2019). Working with this conception of memes as Digital Folklore, I want to suggest that it becomes more apparent how they might fit within museum collecting policies. After all, Owain Rhys' work on contemporary collecting argues that early 'Folklore collections' are the forerunners to contemporary collections in social history museums today (Rhys 2011: 35).

In acknowledging memes as examples of Digital Folklore, we open up the possibilities for us to consider them more readily as new and emerging objects to be collected, representing a wide range of contemporary subjects. Through conversations I've had over the past three to four years, a number of curators have expressed a desire to collect social media content and memes but have articulated that knowing where to start is the problem. However, this does not mean that no attempts have been made. I noted earlier the Museum of London and V\&A's efforts to collect social media. In 2012 the Museum of London collected three Twitter datasets, one relating to the 2012 London Olympics using the hashtag \#CitizenCurator, and two further acquisitions of singular Twitter accounts: the @SaveLewishamA\&E account and the @LondonlsYours account. ${ }^{5}$ In 2021 they announced they had acquired a number of viral tweets, some of which could be argued to be memetic in nature, as part of their Collecting COVID programme. ${ }^{6}$ In 2017 the V\&A acquired a copy of the WeChat social media application, which comprised a version of the app (the .APK file) and a selection of GIFs used in the chat function of the app, alongside their original sketches. ${ }^{7}$ Whilst the acquisitions from both museums have illustrated that it is possible to collect social media and its content, they both have their limitations. The Museum of London Twitter acquisitions resulted in objects that are essentially spreadsheets of data with either screenshots or no associated media. The V\&A acquisition did not include any content from actual users; instead, curators worked directly with the owners of WeChat to populate the app with fictional data. As boundary pushing as these acquisitions are, they miss out some of the fundamental elements that make social media what it is, and also the very essence of what a meme is - participatory, collectively created and remixed media.

There have also been attempts at collecting social media that have more directly interacted with memes. Stockholm County Museum has been actively working to collect born-digital photography posted on social media through its participation in the Collecting Social Photo project and indirectly collected a memetic image as part of their work to collect images of the 2017 Stockholm terror attack. This work on social media photography fell under the museum's collecting policy as a development of their photographic collections. In January 2020 the museum made a decision to begin targeting 'memories on social media' as a collecting avenue, noting how much of the everyday conversation people used to write down now happens on social media and often through the sharing of photos. In order to ensure the museum's approach kept up with the pace of social media conversations, the museum closely observed a variety of social media platforms to react quickly to emerging trends in photo sharing. The \#DollyPartonChallenge meme ${ }^{8}$ became viral during this time and the museum reacted by attempting to collect a number of iterations of the meme (Figure 4) using the same tools and processes used to collect the Stockholm Terror attack meme. ${ }^{9}$ The Stockholm terror attack meme will form the basis of the discussion on the how tho of collecting memes.

To draw this initial exploration of memes as objects of digital cultural heritage to a close I want to reflect on an observation made by Peter Lyman and Howard Besser in 1998. They claim that in the development of new communication media, there comes a moment of realization that its origins are being lost and should be saved; noting that this was true of paper, film, photography, radio, television and sound recordings - and argue that the same will happen for digital works (Lyman and Besser 1998/2010: 337). In 2009, web service Yahoo! shut down Geocities, an early hotbed of online creativity. This act, described by the ArchiveTeam - a collective of self-proclaimed rogue archivists and programmers - successfully destroyed 'the most massive amount of history in the shortest amount of time with absolutely no recourse... Millions of files, user accounts, all gone'.10 Anything of Geocities that is available in web archives today is down to the initial efforts of these rogue archivists (Milligan 


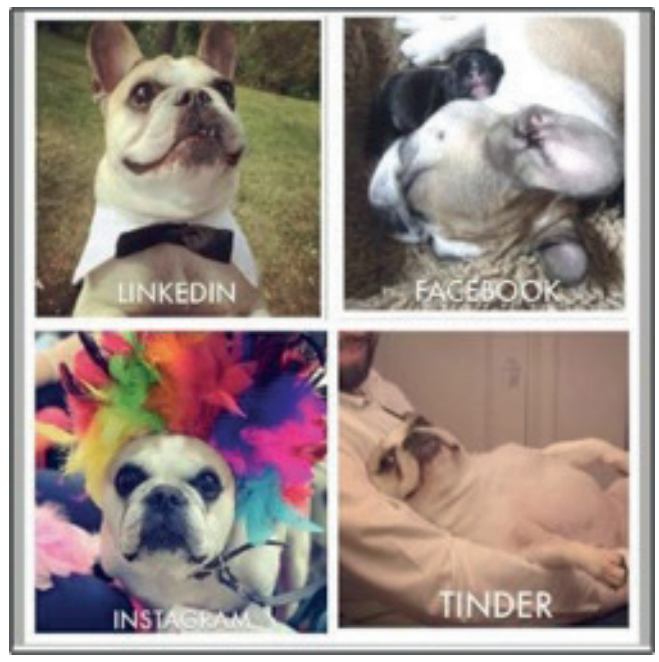

Figure 4. CC BY-NC-SA Fia Sundevall (Stockholm County Museum, DS2 020-00048)
2017: 137). Fast forward ten years and the formative social media platform MySpace loses huge amounts of content uploaded between 2003-15; that is, 'millions of songs, photos and videos with no other home on the Internet'.11 There have already been losses of valuable digital heritage from the Internet and social media's early beginnings and, therefore, I would suggest that we might want to consider whether we have reached Lyman and Besser's moment of realization for online-based communicative practices like memes.

Whilst I do acknowledge that memes may not be relevant for all museums to collect, I believe that they are new and emerging object types that museums need to become more familiar with. They are examples of Digital Folklore - insightful visual markers of creative, often facetious and, at times, divisive public discourses and sharing practices. The question I want to explore from here is how we begin to remix existing practices to adequately collect and represent memes. In order to do that, the next sections will draw out the implications that memes and their complex materiality have for provenance, Copyright and ownership - three key features of established museum acquisition practices. This will be done by working through extracts from my reflexive dyadic interview with Stockholm County Museum.

\section{Insights and methodological choices}

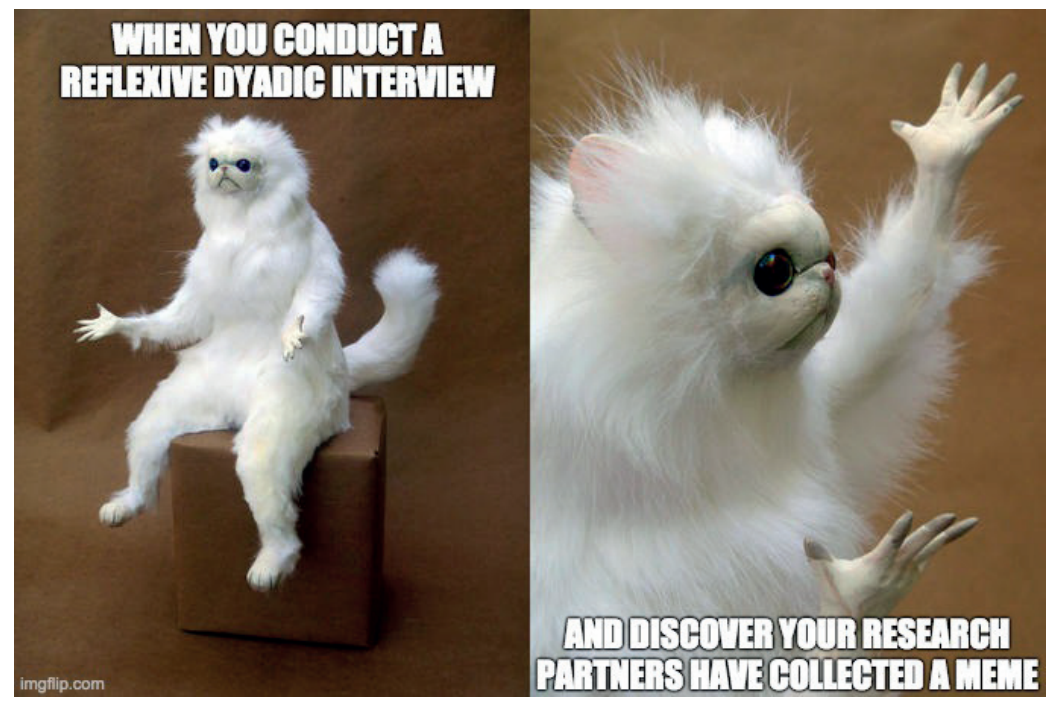

Figure 5. 'Persian cat room guardian' meme created by the author using imgflip.com (14 September 2020) 
Having set up the potential of memes as new and emerging object types, the aim of this section is to set up the case study that was used to draw together this article's proposals for how we might begin collecting memes. The insights stem from my action research with the Collecting Social Photo project over the past three years (2017-2020), and in particular the reflexive dyadic interview undertaken with Elisabeth Boogh, Collections Strategist, and AnnSofie Nygren, Collections Database Manager, at Stockholm County Museum.

The Collecting Social Photo project (CoSoPho) was a three-year research project undertaken by four Nordic institutions: Aalborg City Archives, The Finnish Museum of Photography, Nordiska Museet and Stockholm County Museum. The aim was to develop approaches to collecting social digital photography - that is, born-digital photography, often taken on smartphones and shared through social media (Boogh et al. 2020: 8). Over the three years of the project I observed, interviewed and collaborated as an action researcher. Action research can be described as a form of self-reflective inquiry undertaken in social situations to improve rationality and understanding of practices and the situations in which the practices take place (Kemmis 2008: 122). With respect to my research with CoSoPho, this included contributing to workshops, project decisions, discussing possible implications of the case study findings, and interviewing project partners about the ways in which the research impacted their individual institutions. The act of taking part in practice as a mode of inquiry alerts you to dimensions of your work that have become tacit (Heron and Reason 2008: 370), and it is fair to say that after a number of years working within the sector, the knowledge one has, and the actions one undertakes, become tacit. The rendering of that tacit knowledge has contributed to the lines of inquiry that have led to this article.

Throughout the course of the project, CoSoPho undertook eleven experiments to understand the ways in which museums and archives could best interact with and collect social digital photography. It was through one of these experiments that the Stockholm County Museum first collected a meme. It was not until I was undertaking the reflexive dyadic interview with Elisabeth Boogh and Ann-Sofie Nygren in May 2019 that we really reflected on the fact that one of the images collected as part of the project was in fact a meme. In this case, the reflexive dyadic interviews proved particularly useful in opening up a wide range of topics that developed through discussion, encouragement, laughter and reflection. Carolyn Ellis and Leigh Berger explain how the reflexive dyadic interview results in an interview that feels more like a conversation between equals rather than the often-hierarchical approach to questionand-answer-style interviews (Ellis and Berger 2003: 854). The nature of the relationship I had with Elisabeth prior to the interview, and our free and open sharing of experiences, insights and opinions during it, is what led to the surfacing of the meme being collected. Through discussing the concept of something going viral online, Elisabeth's awareness of my interest in memes and the equal footing on which the interview was set up, we were able to focus in on the fact that an image collected as part of one of the case studies was actually a meme.

The meme that forms the basis of this case study is image based (see Figure 6). It is an image of an eye with the Swedish flag in it and 2017-04-07, the date of the Stockholm terror attack. For the purposes of this article, I will be referring to it as the Swedish eye meme.

The meme was collected using Samtidsbild, a website and app developed by Stockholm County Museum in 2011, born out of the desire to collect contemporary born-digital photography (Boogh 2013: 57). Using the tool, images are uploaded to the museum by anyone who wants to (and has registered and signed up to the terms of service). The uploader is prompted to decide on a Creative Commons licence to apply to the image and agree that the museum can use the images as they like (Boogh 2013: 57). Although the museum does set up specific collecting initiatives, it does not generally apply an active selection process and considers photographs to be accessioned when the user clicks on the final submit button.12

The Swedish eye meme was collected in 2017 when Stockholm County Museum and Nordiska Museet mobilized rapid response collecting initiatives in the wake of the Stockholm terror attack. Stockholm County Museum's initiative, Dokumentation 14:53 was launched three days after the attack and allowed people to upload any images of their choice, without the museum making active selections (Hartig and Boogh 2020: 180). Stockholm County Museum has been actively working to address the mismatch in the way museums acquire physical 


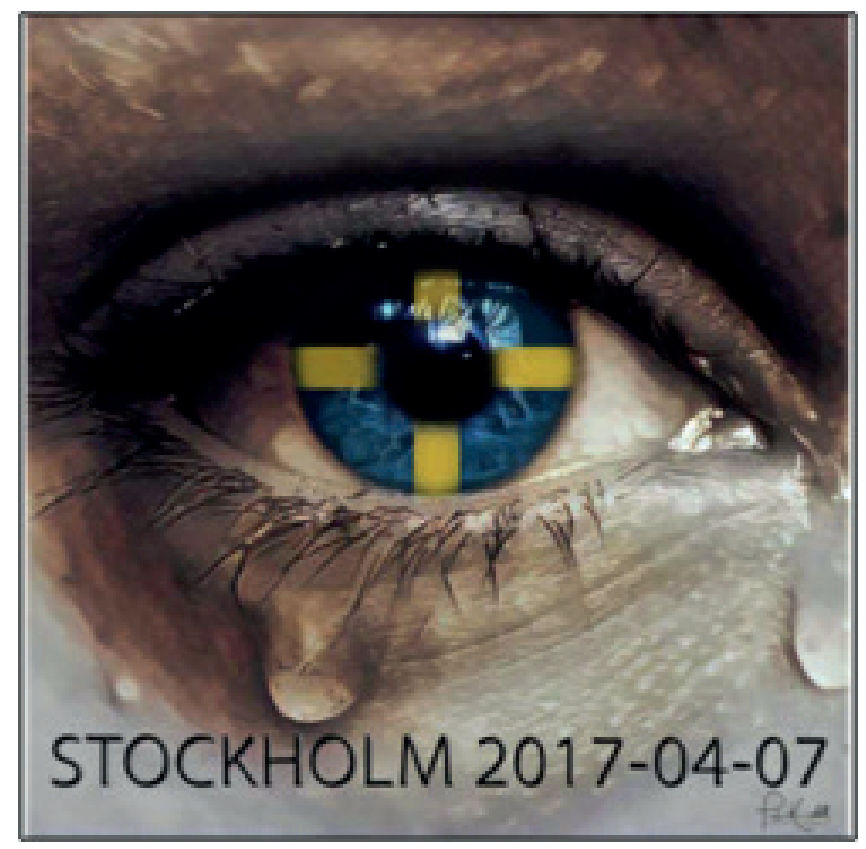

Figure 6. CC BY-NC-ND Peter Kandell (Stockholm County Museum, DS2017-00024)

and digital collections for a number of years (Samtidsbild is an early example of that), and the CoSoPho project has built on that. Although collecting memes was not an identified aim in the museum's experiments as part of CoSoPho, I want to argue that it became achievable through a number of considered choices made in relation to the project and its aims. Stockholm County Museum in particular has been very open about its approach to ownership and the need to work within the same context as where the images are being shared. To this end, the next section focuses on the discussions from the reflexive dyadic interview with added insights from correspondence since, surfacing the specific challenges of collecting memes in museums and illustrating how there are still further complications - meaning the Stockholm County Museum's process is not watertight.

The problem of provenance in remix culture
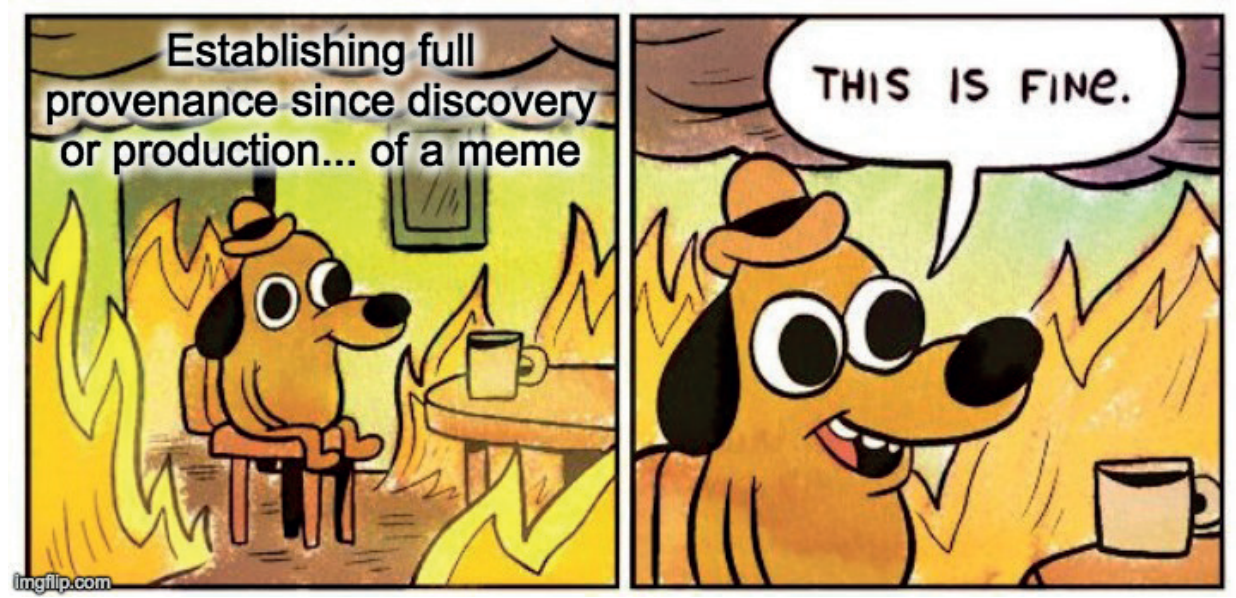

Figure 7. 'This is fine' meme created by the author using imgflip.com (17 September 2020) 
It is the 21 May 2019, I am sitting in a sunny meeting room at the Stockholm County Museum offices. Elisabeth Boogh is sitting opposite me and AnnSofie Nygren to my left. We've spent the last forty-five minutes chatting about Stockholm County Museum, its collection, its history and how it became part of the CoSoPho project. Elisabeth is explaining to me the context of the Swedish eye meme - how she had suspected that the person who uploaded the image was either a professional photographer or had 'nicked' the image and uploaded it for themselves. After contacting them, she found it was the latter - but it was the uploader who had put the Swedish flag in the eye and added the date of the terror attack before sharing it on a range of Facebook groups. The image spread through social media platforms and became appropriated in a range of ways, especially by alt-right groups. ${ }^{13}$

Elisabeth's explanation of how she came to interact with the uploader of the Swedish eye meme surfaces specific issues with provenance and due diligence when considering the how tho of collecting memes in museums. Historically, museums have acquired objects through an array of questionable practices; practices that have been curtailed through international treaties and the development of ethical guidelines by organizations like ICOM - the International Council of Museums. The ICOM Code of Ethics (first edition adopted in 1986) regards its mission to 'set down the internationally accepted foundations that should underpin all other, sometimes more specialised codes' (ICOM 2011: 1). The code addresses standards for collecting and notes specifically on provenance and due diligence that:

Every effort must be made before acquisition to ensure that any object or specimen offered for purchase, gift, loan, bequest, or exchange has not been illegally obtained in, or exported from its country of origin or any intermediate country in which it might have been owned legally (including the museum's own country). Due diligence in this regard should establish the full history of the item since discovery or production (ICOM 2017: 9).

Similar wording over provenance and due diligence can be found in multiple levels of museum standards and processes. For example, Freda Matassa's museum collections management handbook states that 'no object should be acquired if there is any suspicion that it may have been stolen or illegally exported' (Matassa 2011: 157). Whilst I do not disagree with the need for due diligence, the requirement to establish a 'full history of the item since discovery or production' presents quite the challenge to memes and memetic culture.

The provenance of memes is particularly difficult to trace due to the remix cultures they are situated within. To begin with, objects from online environments more generally transcend territorial boundaries, making it difficult to identify what law might apply (Choy et al. 2016: 5). These types of object are likely to be influenced by the hidden algorithms that govern the Internet, algorithms that are 'fundamentally impossible' to document effectively due to their opacity and proprietary natures (Lynch 2017). Despite this, attempts to record the provenance of objects from online contexts is not futile in all cases; metadata associated with some digital objects spell out clear provenance, for example, a Tweet accessed through the Twitter API (application programming interface) will contain information on the creator, the date and location (in some instances where the user has allowed Twitter access to their location) ${ }^{14}$ However, the provenance of a meme has additional complications. Anisa Hawes and Catherine Flood explain how memes are created through repeated exchanges, where they are made and remade by many different people. This unsettles the notion of an original creator that has developed through a culture that has 'privileged original objects created by identifiable creators' ${ }^{15}$ In memetic cultures, the original creator becomes no more or less important than the latest creator. Jason Eppink argues further that memes (GIFs in Eppink's case) actually de-emphasize authorship, claiming that a successful meme is one that is 'shared, eclipsing its creator to become an essential part of a cultural conversation' (Eppink 2014: 301). Here we see how the success or significance of a meme makes its full provenance more difficult to establish. 
In the case of the Swedish eye meme, the person who uploaded it was not the photographer, but was the meme creator. Elisabeth's use of the word 'nicked' when discussing the meme with me implies that there is a belief that, in the creation of the meme, the original image may have been stolen or illegally obtained. This uneasiness with the practices of the social web, where the majority of remix culture arguably takes place, is discussed by Ross Parry. Parry situates the social web as anomic, where questions of trustworthiness and authenticity, coupled with eroding distinctions between amateur and professional, are problematic for museums (Parry 2013: 18). This general distrust of online practices has implications for the decision that curators make on whether or not objects like memes can be collected. Parry explains how, in working within online contexts, museum professionals tend to revert to more traditional ways of thinking and doing things (Parry 2013: 18), but with Stockholm County Museum, despite the implication that the meme was probably created through the stealing of an image, the decision was made not to stop the acquisition. This indicates that Elisabeth, and the museum more generally, are working more productively with the web and its affordances.

The wording around provenance and due diligence explicitly asks us to consider the legal issues surrounding an object. The legality of creating a meme from an existing image is ambiguous. Lawrence Lessig makes the claim that under Copyright law, all forms of digital remix are actually illegal (Lessig 2008: 98-9). However, there are also aspects of law that consider the act of making a meme a creative act that results in new Copyright - this will be addressed in more depth in the discussion on Copyright next. What is important to highlight here is that the decision as to whether an object can be acquired, if there are deemed to be gaps in provenance, is at the discretion of the museum. I remember this being a constant source of anxiety for curators responsible for collecting new types of object in the training I used to deliver alongside the registrars at the $\mathrm{V} \& \mathrm{~A}$. However, through accepting the affordances of remix cultures, it is possible to avoid more readily the reversion to more traditional modes of practice as described by Parry, at least in the case of social media and meme related objects. Elisabeth's orientation towards working within digital culture and social media contexts meant that despite an underlying feeling that the original photograph was 'nicked', there was the confidence in the ordinariness of this practice in the cultural contexts she was collecting from. Therefore, I propose that we need to consider explicitly how museum acquisition practices can become more familiar with the web, and especially remix culture's anomic qualities.

\section{The Copyright question}

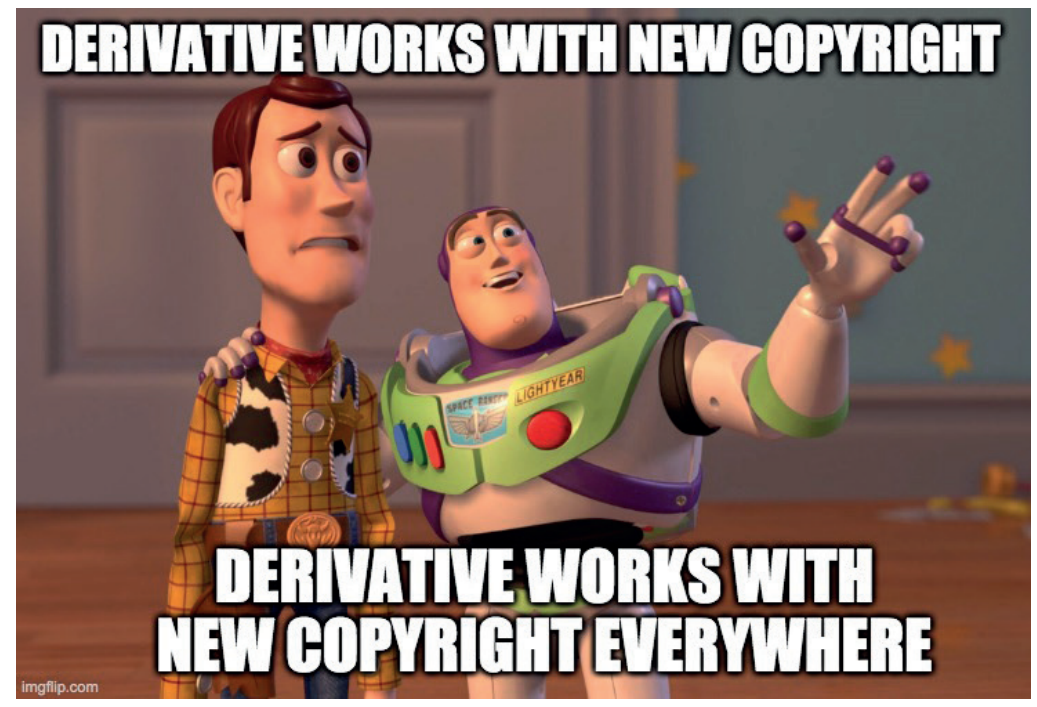

Figure 8. Toystory ' $X, X$ Everywhere' meme created by the author using imgflip.com (17 September 2020) 


\begin{abstract}
After discussing the details and associations of the Swedish eye meme, Elisabeth receives a brief tongue-in-cheek telling off from Ann-Sofie for not having documented the story fully in the collections management system yet. We laugh and agree that it'll be done asap. We continue to discuss the importance of trying to capture how memes and social digital photographs more generally circulate through social media platforms. Elisabeth reflects on the fact that collecting the Swedish eye meme was challenging for the museum because of its Copyright status: 'the original photographer of that eye may not have wanted to share it. You know, it might not have an open licence... Probably not', but follows up that, due to its size, the museum is more able to have these conversations internally and take risks. I agree, but want to probe how much of a risk it actually was - I question whether the image in question is actually protected under its own Copyright due to the modifications that had been made to it, but Elisabeth isn't convinced - suggesting that if there were 'a lawsuit then it might be difficult for the person who made these modifications.'.16
\end{abstract}

This exchange over Copyright and the challenge this meme presented to the museum opens up particularly pertinent questions on how Copyright interacts with memes and remix culture, and the risk appetite required to engage in collecting in online environments. The question of Copyright began creeping into the discussion on provenance, but Elisabeth's direct reference to it as a challenge to the museum warrants further discussion here.

The application of Copyright to born-digital materials is an ongoing complex issue. As noted, Lessig's work on remix culture highlights how all forms of remix are technically illegal - but his discussion on Copyright goes further than that. Lessig highlights how, in theory, any interaction with a digital file triggers Copyright; even when simply opening a digital file, it is copied from one place to another and changed in some way (Lessig 2008: 88-9). UNESCO first acknowledged the need to protect digital material through its Charter on the Preservation of Digital Heritage. ${ }^{17}$ However, today there remains very little legislative support for preserving born-digital content under Copyright. In European law there are exceptions to Copyright with regards to making copies for preservation purposes, but these exceptions tend to be in relation to analogue content that is being digitized. The European Union's 2019 Directive on Copyright in the Digital Single Market made a number of changes to Copyright with respect to digital culture, but Michal Koščík and Matěj Myška argue that born-digital content and its relationship to cultural heritage institutions remains largely ignored (Koščík and Myška 2019: 13).

With regards to Copyright and memes, there are only a handful of legal cases where there has been a dispute and legislation has been put to the test. In the lead up to the vote on the 2019 Directive on Copyright in the Digital Single Market, article 13 of the directive was touted by many online commentaries as a 'meme ban'. The claim was that the EU's attempt to place the onus of blocking the uploading of Copyrighted materials onto online platforms would lead to memes being blocked. The European Commission directly addressed the issue, stating that memes were protected as they are classified as caricature, parody or pastiche. ${ }^{18}$

In the discourse, memes are most commonly positioned as valid acts of creativity that create new derivative works and constitute new Copyright (Bonetto 2018, Marciszewski 2020). This positioning of memes as new derivative works is not disputed by Elisabeth, but rather the extent to which the Swedish eye meme could be considered an act of creativity. Whilst there may have been limited editing of the original photograph, Mark Marciszewski explains how the threshold of creativity needed for Copyright protection is 'extremely low' and that allows for the vast majority of memetic images to be protectable (Marciszewski 2020: 69). The remixed ' $y$ tho' meme that I used to open this article is a great example of a relatively low level of creative intervention (without doing myself too much of a disservice) that has resulted in my own derivative work and new Copyright that I arguably own. As with provenance, it is important to note that Elisabeth's reticence over the validity of the meme as a creative act did not stop the museum in collecting it. The museum's recognition of the social media environment and remix cultures, along with its open approach to risk, meant that the challenges Elisabeth talks of did not become insurmountable barriers to collecting.

Although we did not dwell on the Copyright challenges the meme presented the museum during the interview, it is worth exploring the role of Copyright in collecting memes 
a little further. The ability of meme creators to be able to claim some level of Copyright or ownership over the meme is important for museum acquisition practices in their current form. The assignment of Copyright has been a central part of acquisition practices for a number of years and is most often considered to be 'the best outcome for any museum' (Matassa 2011: 16). However, I want to suggest that the assignment of Copyright in a meme for a museum would not be particularly productive considering the Copyright holder's lack of ability to fix and control memes that exist online.

One of the underpinning logics of the museum is to preserve tangible material, and in doing so the focus has been on collecting material things as they become valued, and working to keep them unchanged (Knell et al. 2007: xix). Digital objects have presented themselves as problematic to this approach through their lack of fixity both inside and outside of the museum's context. This directly challenges museum professionals' ability to manage their materiality and keep things unchanged using traditional methods (Cameron and Kenderdine 2007; Paul 2008, 2012)..$^{19}$ Whilst a number of museums have been tentatively collecting digital objects, the Culture Shock! project presents an interesting approach to attempting to deal with fixity through the assigning of Copyright. Between 2008 and 2010 Tyne \& Wear Archives and Museums led a contemporary collecting project called Culture Shock!, in which over 500 community-made digital stories were created and collected. The digital stories were formally acquired through a process that saw the signing over of Copyright as a transfer of title. The logic behind this was that the act of signing over of Copyright in the digital objects marked them as fixed, complete, and ready to be collected (Graham et al. 2013: 110-2).

In the case of the Swedish eye meme and memes more generally, this is not plausible. The memes exist in social media, multiple copies of them can be reappropriated and remixed further and in such memetic landscapes it is difficult to track who owns, breaks or creates the Copyright. ${ }^{20}$ In their conclusions on the use of Copyright in the Culture Shock! Project, Graham et al. note that its use in collecting digital objects was not particularly helpful given the realities of the controllability of digital objects. ${ }^{21}$ Similarly, Stockholm County Museum recognized that it did not need to control how the memes were used outside the museum for it to form part of the collection. This recognition will become more important as we look next at how the museum utilizes Creative Commons licensing to interact with Copyright, and how the museum conceives its ownership of the meme as an object in its collection.

\section{An indisputable right to shared ownership of [virtual] property?}

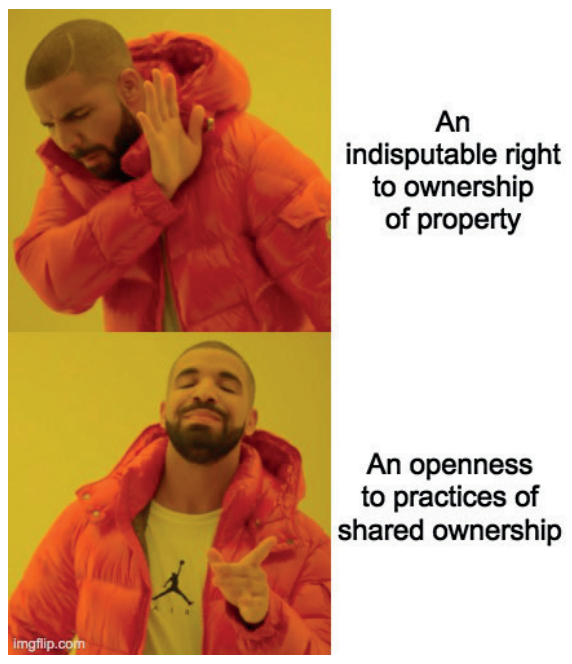

Figure 9. 'Drake Hotline Bling' meme created by the author using imgflip.com (17 September 2020) 
It's after lunch - the biscuits are out; we've had coffee from their fancy coffee machine and we're looking through the museum's collections management database together. I ask what I know might be a bit of a knotty question - what is the legal status of the photographs uploaded to Samtidsbild? I follow up more explicitly by asking 'Do they go into the museum's ownership or what kind of agreement is signed compared to if you donated a physical object to the museum?' Elisabeth answers instantly 'it's a shared ownership' - the museum does not claim individual ownership over the photos and the uploader gives usage rights to the museum under Creative Commons licensing. When questioned further on whether there was any nervousness about the lack of control over the photographs, Elisabeth explains how it wasn't something that had been expressed or discussed in the museum and that, whilst full ownership would be easier, the museum has undertaken many collection projects where there is 'combined ownership between the photographer and the museum', citing examples of where analogue photography has entered the museum, been digitized and later returned. ${ }^{22}$

It was during this part of the interview that I began to fully understand how it was Stockholm County Museum's remixed approach to collecting social digital photography that made collecting memes possible for them. Although in this part of the interview we are speaking more generally about collecting through the tool Samtidsbild, it dawned on me that the museum's unquestioning openness to the idea of their collections not being exclusively owned by the museum is the most important part of their practice that enables the acquisition of memes and memetic media.

That being said, the concept of shared ownership that Elisabeth declared does unsettle some of the foundational notions of acquisition in museums codified through the ICOM Code of Ethics. The code insists that: 'No object or specimen should be acquired by purchase, gift, loan, bequest, or exchange unless the acquiring museum is satisfied that a valid title is held. Evidence of lawful ownership in a country is not necessarily valid title' (ICOM 2017: 9). Valid title is clarified further in the glossary as an 'indisputable right to ownership of property, supported by full provenance from the time since discovery or production' (ICOM 2017: 49). The Acquisition and Accessioning procedure in Spectrum 5.0 - the UK collections management standard that is also used in Sweden - follows closely that as a minimum requirement 'you have written evidence that the undisputed owners of acquired objects have transferred title to your museum'. ${ }^{23}$ As early as 2013, Kalliopi Fouseki and Kalliopi Vacharopoulou argued that the ICOM's Code was out of touch with the implications of the digital age, citing the focus on ownership as problematic (Fouseki and Vacharopoulou 2013: 8). That argument still stands today. What makes this focus on ownership problematic for memes and the digital social photography Elisabeth, Ann-Sofie, and I were discussing is the idea of an 'indisputable right to ownership of property' and how that translates from discrete and fixed tangible objects to memes.

Legal scholars Aaron Perzonowski and Jason Schultz explain that what it means to own property is a surprisingly complex question to address - arguing that the dominant view of it bestowing an absolute right to an individual owner of a tangible material thing is an oversimplification (Perzanowski and Schultz 2016: 20). They explain that there are four basic types of property: real, personal, intellectual and intangible. Real and personal property both relate to physical assets, whilst Intellectual Property (IP) covers both physical and digital, and intangible property covers intangible assets not covered by IP such as interest in debts or licences, etc. (Perzanowski and Schultz 2016: 15-9). There have also been attempts at defining virtual property in the context of digitally created goods in 'virtual worlds' (Chein 2006; Vacca 2008) and digital items not generally governed by IP like email accounts (Fairfield 2005: 1049). However, limited application of this within legal systems means it is difficult to establish if the digital image or video files that often form the material essence of a meme constitute virtual property.

One of the more useful distinctions to work with came from Steve Horowitz who noted that in digital goods, virtual property is best understood in discussing 'rivalrous goods' whilst IP is better suited to 'nonrivalrous goods' (Horowitz 2006: 444). Therefore, the question of whether a museum can confidently state that it has the indisputable right to ownership of a 
meme as virtual property comes down to whether or not they are rivalrous goods - whether one person's use of a digital item impedes on another's use of it (Fairfield 2005: 1052). Recent developments in blockchain technology have led to the use of 'non-fungible tokens' (NFTs) as a way of certifying ownership in digital goods. This practice has been applied to the sale of digital artworks and NFTs and other blockchain technologies are beginning to be explored for use within the cultural sector more widely. ${ }^{24}$ I have no doubt that there will be work to explore how NFTs could be used in digital acquisitions in the future, but they have not been used in that way so far.

Our understanding of ownership is also key to working through the further applicability of shared or alternative forms of ownership of memes as property. General comprehensions of ownership see it as the 'exclusive right to use, possess, and dispose of property' (Law 2018: 224 ) or the ability to exercise rights and control over property that are not generally subject to a third party (Zhou et al. 2018: 58). It is within these understandings that museums tend to operate; as Matassa tells us - the museum 'wants to receive the object unencumbered and to be able to do exactly as it wishes with the object for all time' (Matassa 2011: 151). However, a more nuanced take on ownership is described by Perzonowski and Schulz who sees it as a 'bundle of related but separable rights' (Perzanowski and Schultz 2016: 21). In considering ownership as separable rights, we begin to open up the possibilities of shared or alternative forms of ownership being valid options.

Stockholm County Museum is not alone in its steps towards more shared approaches to ownership within the museum sector. Janet Marstine et al. have explored what is required for a twenty-first century approach to ethical museum work and focused one of the strands of their research on alternative ownership models for collections. Through that, a number of concerns over the museum's focus on ownership of property in isolation from their communities emerged, and Marstine et al. conclude that there is a general aspiration to 'reject the conventions of museum possession/ownership of collections' (Marstine et al. 2015: 81). Instead, Marstine suggests moving towards a more ethical form of stewardship that does not focus on exclusive ownership (Marstine 2017: 46). Other calls for more democratic forms of collecting and curatorship have come from Sophia Lui who suggests a socially distributed curation method to produce shared ownership over objects of living memory (Lui 2012: 52). The approach taken by Stockholm County Museum does just that - it promotes a shared approach to social digital photography where they understand the photographs collected through Samtidsbild as shared cultural heritage.

A deeper look into the how tho of collecting using a tool like Samtidsbild led me to the terms of service. They illustrate how the museum is actually working on a similar licence model to social media platforms like Twitter and Instagram. The Twitter and Instagram terms of service stipulate that they do not claim ownership over the content and that it remains with the user. However, the agreements do give the platforms a worldwide non-exclusive, royalty-free, transferable, sub-licensable, licence to host, use, distribute, modify, run, copy, publicly perform or display, translate, and create derivative works of the content uploaded. ${ }^{25}$ The Samtidsbild terms of service similarly stipulate that by uploading, a user grants 'a nonexclusive right of use to Stockholm County Museum to... produce copies and in other ways make messages available to the public'. They also state that 'Stockholm County Museum has the right to place the publication on another's website, on social media or a search portal on the Internet', and also that 'Nothing in these sections restricts the User's right to use its content on its own' ${ }^{26}$

What is particularly interesting here is that the museum has developed an agreement around the collecting of digital photography that uses the same model of the social media platforms on which people are used to sharing photos, deciding that it does not need to directly assert ownership in order to collect. Therefore, although Elisabeth stated that there is a shared ownership, the terms of service do not directly address this. This is potentially problematic as the status of the photographs becomes less clear. Elisabeth highlights a little later on in the interview that people who are uploading have to use Creative Commons licensing and that doing that can be problematic in itself:

we're not entirely sure that people know what Creative Commons are... I've seen that people are not sure... it's one thing that the museum can use a photograph, but the Creative Commons licence also gives anybody else the right to use it... and I don't know that people are really aware about that. ${ }^{27}$ 
Without there being an explicit reference to the images becoming part of the museum's collection, along with the lack of awareness about the nature of Creative Commons licensing, it is possible that some people do not fully understand what is happening when they upload an image onto Samtidsbild. This is something that I would propose should be more explicit in the collecting process. That being said, the museum has been collecting digital photography in this way since 2011 and Elisabeth and Ann-Sofie confirmed that there have been no enquiries made about the museum's use of images in that time.

\section{Conclusions}

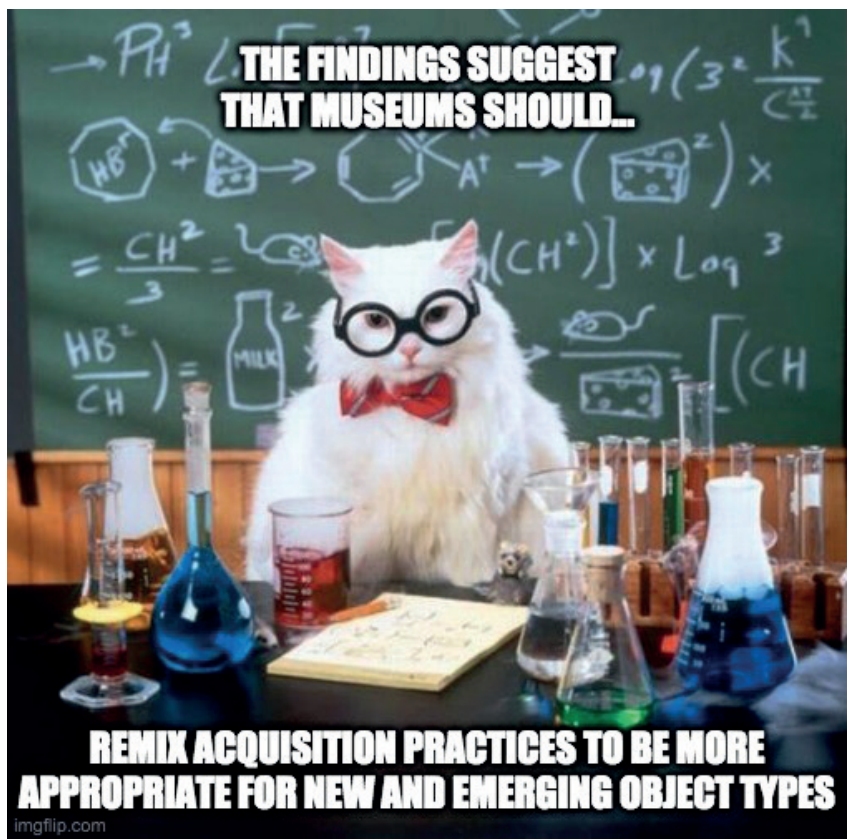

Figure 10. 'Chemistry cat' meme created by the author using imgflip.com (28 September 2020)
This article has had two key aims: to situate memes as new and emerging object types formuseums to become more conscious of; and to address how in collecting such objects, museums need to begin to consider remixing their acquisition processes to make them more appropriate to their materiality and the contexts from which these objects are being collected. Its purpose was not to set out a concrete process for collecting memes, but to surface the issues and make preliminary suggestions based on the work of Stockholm County Museum. In the process, I have harnessed memes as miniature mindbombs to the written and established processes that many museums adhere to when acquiring collections.

Through exploring the how tho of the memes collected by the Stockholm County Museum, this article has highlighted some of the implications for provenance, Copyright and ownership - three key features of museum acquisition processes. The ways in which Stockholm County Museum have been able to collect memes illustrates that if museums remix their collecting practices to make them more appropriate for the contexts that they are collecting from, then memes and other new and emerging object types do not present insurmountable problems that make collecting them impossible.

In Stockholm County Museum accepting that they cannot fully own social digital photographs and managing their ability to use them as any other object in their collection through existing processes like Creative Commons licensing and online-specific terms and conditions, the museum has utilized existing frameworks for managing digital content to remix their approach to collecting. As a result, the museum has developed an approach that results in a more appropriate mode of collecting objects born out of remix and those that come from online and social media contexts, whilst not undermining what the museum is able to do with its objects. Although the exploration of the issues has shown that there is room for improvement in some of the ways the museum ensures clarity over the status of collected objects, by adopting what I consider a remix approach to collecting new and emerging object types, there is scope for the museum to adapt their processes relatively easily moving forwards.

Received: 20 January 2020

Finally accepted: 1 June 2021 


\section{Notes}

1 The Collecting Social Photo (2017-2020) website contains further information about the project: http://collectingsocialphoto.nordiskamuseet.se/, accessed 22 September 2020.

2 Bergis Jules, 'Some Thoughts on Ethics and DocNow', Documenting DocNow 3 June 2016. https://news.docnow.io/some-thoughts-on-ethics-and-docnow-d19cfec427f2, accessed 12 June 2021; Bergis Jules, Ed Summers, Vernon Mitchell, Jr., 'Documenting the Now White Paper: Ethical Considerations for Archiving Social Media Content Generated by Contemporary Social Movements: Challenges, Opportunities, and Recommendations', Documenting the Now April 2018. https://www.docnow.io/docs/docnow-whitepaper-2018. pdf, accessed 12 June 2021.

3 Rhizome is a non-profit arts organization focusing on digital and new media art,with a particular focus on online or Internet art. It was founded by artist Mark Tribe as a listserv in the late 1990s and became formally affiliated with the New Museum in New York in 2003. https://rhizome.org/about/, accessed 12 March 2021.

4 The statement is no longer available on the Hillary Clinton campaign website, but can be accessed through the Internet Archive at https://web.archive.org/web/20160914040646/ https://www.hillaryclinton.com/feed/donald-trump-pepe-the-frog-and-white-supremacistsan-explainerl, accessed 12 March 2021.

5 Foteini Aravani, interview by author, digital recording, 7 February 2020, London.

6 Museum of London blog piece announcing the acquisition of 13 viral tweets as part of the museum's Collecting COVID programme. Museum of London, 'Museum of London Acquires "viral" Tweets for Collecting COVID', 28 January 2021. https://www.museumoflondon. org.uk/news-room/press-releases/museum-Iondon-acquires-tweets, accessed 12 March 2021.

7 Brendan Cormier and Esme Hawes, interview by author, digital recording, 18 October 2019, London.

8 The \#DollyPartonChallenge meme began in January 2020 when Dolly Parton shared four images of herself captioned with different social media platform names (Linkedln, Facebook, Instagram and Tinder). The meme plays on the fact that as social media users we present different versions of ourselves on different platforms.

9 Elisabeth Boogh, Collections Strategist, Stockholm County Museum, personal communication, 21 September 2020.

10 ArchiveTeam, 'Geocities', 2021. https://www.archiveteam.org/index.php/GeoCities, accessed 12 March 2021.

11 Alex Hern, 'Myspace Loses All Content Uploaded Before 2016', The Guardian 2019. https:// www.theguardian.com/technology/2019/mar/18/myspace-loses-all-content-uploadedbefore-2016, accessed 12 March 2021.

12 Elisabeth Boogh, pers. comm., 21 September 2020.

13 Elisabeth Boogh and Ann-Sofie Nygren, interview by author, digital recording, 19 May 2019, Stockholm.

14 Dan Kerchner, Justin Littman, Christine Peterson, Vakil Smallen, Rachel Trent and Laura Wrubel, 'The Provenance of a Tweet', 14 June 2016. https://scholarspace.library.gwu.edu/ work/r207tp65z, accessed 12 June 2021. 
15 Anisa Hawes and Catherine Flood, 'Curating and Collecting Digital Posters Handbook', 2018. https://ccdgp.co.uk/colophon.html, accessed 12 June 2021.

16 Elisabeth Boogh and Ann-Sofie Nygren, interview, 19 May 2019.

17 UNESCO, 'Charter on the Preservation of Digital Heritage', 2003. http://portal.unesco.org/ en/ev.php-URL ID=17721\&URL DO=DO TOPIC\&URL SECTION=201.html, accessed 12 June 2021.

18 European Commission, 'No, No, No, We Are Not Banning Memes!', 16 November 2018. https://medium.com/@EuropeanCommission/https-medium-comeuropeancommission-no-no-no-we-are-not-banning-memes-Copyright-proposalabf4d21f65d2, accessed 12 June 2021.

19 Digital preservation discourses now make clear that change is part of the preservation of digital materials. It is positioned as a management issue (rather than a purely technical one) that requires changes to features of the object like its file format in order to keep it accessible (Corrado and Sandy 2017).

20 Cristina Hanganu-Bresch, 'What's in a Meme?', The 2016 CCCC Intellectual Property Annual: Top Intellectual Property Developments of 20162017 16-23. https://cdn.ncte.org/ nctefiles/groups/cccc/committees/ip/2016/topip2016collection.pdf, accessed 12 March 2021.

21 Helen Graham, Rhiannon Mason and Nigel Nayling, 'Earning Legitimacy: Participation, Intellectual Property and Informed Consent', 2012. https://partnershipandparticipation. files.wordpress.com/2012/07/earninglegipicjuly2012.pdf, accessed 12 March 2021.

22 Elisabeth Boogh and Ann-Sofie Nygren, interview, 19 May 2019.

23 Collections Trust, 'Spectrum 5.0: Acquisition and Accessioning'. https:// collectionstrust.org.uk/spectrum/procedures/acquisition-and-accessioningspectrum-5-0/, accessed 12 June 2021.

Blockchain technology uses a system of recording information that makes it (so far) impossible to change and hack what is recorded. NFTs are crypto-tokens that use blockchain technology and have been utilized to verify digital ownership. They are increasingly used in art sales (see Beeple’s $£ 50 \mathrm{~m}$ sale at Christie’s in March 2021) and conferences like Exploring Blockchain in the Cultural Sector that took place in October 2020 are beginning to draw out potential uses for museums (see Frances Liddell, "'Exploring Blockchain in the Cultural Sector" Highlights', Researching Digital Cultural Heritage 16 November 2020. https://digitalheritageresearch.wordpress.com/author/francesliddell94/accessed 12 March 2021).

25 Instagram, 'Terms of Use', 2021. https://www.facebook.com/help/Instagram/termsofuse, accessed 12 June 2021; Twitter, 'Twitter Terms of Service', 2021. https://twitter.com/en/ $\underline{\text { tos, }}$ accessed 12 June 2021.

26 Samtidsbild, 'User Terms and Conditions', 2021. https://samtidsbild.se/index.php/About/ userterms, accessed 12 March 2021. The wording was translated from Swedish using Google Translate.

27 Elisabeth Boogh and Ann-Sofie Nygren, interview, 19 May 2019. 


\section{References}

Bonetto, G. (2018) 'Internet Memes as Derivative Works: Copyright Issues under EU Law', Journal of Intellectual Property Law \& Practice, 13 (12) 989-97.

Boogh, E. (2013) 'Samtidsbild/Contemporary Images - A Method of Collecting Vernacular Photography in the Digital Age', Museum International, 65 (1-4) 54-67.

Boogh, E., Hartig, K., Jensen, B., Uimonen P. and Wallenius, A. (eds) (2020) Connect to Collect: Approaches to Collecting Social Digital Photography in Museums and Archives, Stockholm: Nordiska museets förlag.

Bradbury, H. (ed) (2015) The SAGE Handbook of Action Research, Los Angeles: SAGE.

Brügger, N. and Schroeder, R. (2017) The Web as History: Using Web Archives to Understand the Past and the Present, London: UCL Press.

Cameron, F. and Kenderdine, S. (eds) (2007) Theorizing Digital Cultural Heritage: A Critical Discourse, Cambridge, Mass. and London: MIT Press.

Chein, A. (2006) 'A Practical Look at Virtual Property', St. John's Law Review, 80 (3) 105990.

Choy, S.C.C., Crofts, N., Fisher, R., Choh, N.L., Nickel, S., Oury, C. and Ślaska, K. (2016) The UNESCO/PERSIST Guidelines for the Selection of Digital Heritage for Longterm Preservation, UNESCO.

Corrado, E.M. and Sandy, H.M. (2017) Digital Preservation for Libraries, Archives, and Museums, London: Rowman \& Littlefield Publishers.

Dawkins, R. (2006) The Selfish Gene, Oxford: Oxford University Press.

Denisova, A. (2019) Internet Memes and Society: Social, Cultural, and Political Contexts, Abingdon and New York: Routledge.

de Seta, G. (2019) 'Digital Folklore' in Jeremy Hunsinger, Lisabeth Klastrup and Matthew M. Allen (eds) Second International Handbook of Internet Research, 167-80, Dordrecht, Springer Netherlands.

Ellis, C., Adams, T.E. and Bochner, A.P. (2011) 'Autoethnography: An Overview', Forum: Qualitative Social Research, 12. DOI: 10.17169/fqs-12.1.1589.

Ellis, C. and Berger, L. (2003) 'Their Story/My Story/Our Story: Including the Researcher's Experience in Interview Research', in Jaber F. Gubrium and James A. Holstein (eds) Postmodern Interviewing, 849-75, Thousand Oaks, California: SAGE Publications.

Eppink, J. (2014) 'A Brief History of the GIF (So Far)', Journal of Visual Culture, 13 (3) 298306.

Espenschied, D. and Lialina, O. (2009) Digital Folklore, Stuttgart: Merz \& Solitude.

Esteves, V. and Meikle, G. (2015) '"Look@ this Fukken Doge”: Internet Memes and Remix Cultures', in Chris Atton (ed) The Routledge Companion to Alternative and Community Media, 561-70, Abingdon and New York: Routledge.

Fairfield, J.A.T. (2005) 'Virtual Property’ Boston University Law Review, 85 (4) 1047-102. 
Fouseki, K. and Vacharopoulou, K. (2013) 'Digital Museum Collections and Social Media: Ethical Considerations of Ownership and Use', Journal of Conservation and Museum Studies, 11 (1) 1-10.

Graham, B. (ed) (2014) New Collecting: Exhibiting and Audiences after New Media Art, Farnham and Burlington: Ashgate Publishing Ltd.

Graham, H., Mason, R. and Nayling, N. (2013) 'The Personal is Still Political: Museums, Participation and Copyright', Museum and Society, 11 (2) 105-21.

Hartig, K. and Boogh, E. (2020) 'The 2017 Stockholm Terrorist Attack: Rapid Response Collecting', in Elisabeth Boogh, Kajsa Harting, Bente Jensen, Paula Uimonen and Anni Wallenius (eds) Connect to Collect: Approaches to Collecting Social Digital Photography in Museums and Archives, 176-90, Stockholm: Nordiska museets förlag.

Heron, J. and Reason, P. (2008) 'Extending Epistemology within a Co-operative Inquiry', in Peter Reason and Hilary Bradbury (eds) The SAGE Handbook of Action Research: Participative Inquiry and Practice, 366-80, Thousand Oaks, California: SAGE Publications.

Horowitz, S.J. (2006) 'Competing Lockean Claims to Virtual Property Note', Harvard Journal of Law \& Technology, 20 (2) 443-58.

ICOM (2011) Checklist on Ethics of Cultural Property Ownership, Paris: ICOM Ethics Committee.

(2017) ICOM Code of Ethics for Museums, ICOM.

Kemmis, S. (2008) 'Critical Theory and Participatory Action Research' in Peter Reason and Hilary Bradbury (eds) The SAGE Handbook of Action Research: Participative Inquiry and Practice, 121-38, Thousand Oaks, California: SAGE Publications.

Knell, S.J., MacLeod, S. and Watson, S. (eds) (2007) Museum Revolutions: How Museums Change and are Changed, Abingdon and New York: Routledge.

Koščík, M. and Myška, M. (2019) 'Copyright Law Challenges of Preservation of "Borndigital” Digital Content as Cultural Heritage', European Journal of Law and Technology, 10 (1) 1-21.

Law, J. (2018) A Dictionary of Law, Oxford: Oxford University Press.

Lessig, L. (2008) Remix: Making Art and Commerce Thrive in the Hybrid Economy, London: Penguin.

Lui, S. (2012) 'Socially Distributed Curation of the Bhopal Disasters: A Case of Grassroots Heritage in the Crisis Context', in Elisa Giaccardi (ed) Heritage and Social Media: Understanding Heritage in a Participatory Culture, 30-55, London and New York: Taylor \& Francis.

Lyman, P. and Besser, H. (1998/2010) 'Defining the Problem of our Vanishing Memory: Background, Current Status, Models for Resolution', in Ross Parry (ed) Museums in The Digital Age, 336-43, Abingdon and New York: Routledge.

Lynch, C. (2017) 'Stewardship in the "Age of Algorithms”', First Monday, 22 (12).

Marciszewski, M. (2020) 'The Problem of Modern Monetization of Memes: How Copyright Law Can Give Protection to Meme Creators', Pace Intellectual Property, Sports \& Entertainment Law Forum, 9 (1) 61-105. 
Marstine, J. (2017) Critical Practice: Artists, Museums, Ethics, Abingdon and New York: Routledge.

Marstine, J., Dodd, J. and Jones, C. (2015) 'Reconceptualising Museum Ethics for the Twenty-first Century Museum', in Conal McCarthy (ed) Museum Practice, 69-96, Chichester: John Wiley \& Sons Ltd.

Matassa, F. (2011) Museum Collections Management, London: Facet.

Metahaven (2013) Can Jokes Bring Down Governments?: Memes, Design and Politics, Moscow: Strelka Press.

Milligan, I. (2017) 'Welcome to the Web: The Online Community of GeoCities During the Early Years of the World Wide Web', in Niels Brügger and Ralph Schroeder (eds) The Web as History: Using Web Archives to Understand the Past and the Present, 137-58, London: UCL Press.

Milner, R.M. (2016) The World Made Meme: Public Conversations and Participatory Media, Cambridge, Mass.: The MIT Press.

Navas, E., Gallagher, O. and burrough, x. (eds) (2015) The Routledge Companion to Remix Studies, Abingdon and New York: Routledge.

Ngai, S. (2017) 'Theory of the Gimmick', Critical Inquiry, 43 (2) 466-505.

Parry, R. (2013) 'The Trusted Artifice: Reconnecting the Museum's Fictive Tradition Online' in Kirsten Drotner and Kim Christian Schrøder (eds) Museum Communication and Social Media: The Connected Museum, 17-32, Abingdon and New York: Routledge.

Paul, C. (ed) (2008) New Media in the White Cube and Beyond: Curatorial Models for Digital Art, Berkeley: University of California Press.

(2012) 'The Myth of Immateriality - Presenting New Media Art', Technoetic Arts, 10 (2-3) 167-72.

(2016) A Companion to Digital Art, Hoboken: Wiley Blackwell.

Perzanowski, A. and Schultz, J.M. (2016) The End of Ownership: Personal Property in the Digital Economy, Cambridge, Mass.: The MIT Press.

Phillips, W. and Milner, R.M. (2017) The Ambivalent Internet: Mischief, Oddity, and Antagonism Online, Cambridge: Polity Press.

Rhys, O. (2011) Contemporary Collecting: Theory and Practice, Edinburgh: Museums Etc.

Shifman, L. (2014) Memes in Digital Culture, Cambridge, Mass.: The MIT Press.

Vacca, R. (2008) 'Viewing Virtual Property Ownership through the Lens of Innovation', Tennnessee Law Review, 76 (1) 33-66.

Zhou, M., Leenders, M.A.A.M. and Cong, L.M. (2018) 'Ownership in the Virtual World and the Implications for Long-term User Innovation Success', Technovation, 78 56-65.

Zulli, D. and Zulli, D.J. (2020) 'Extending the Internet Meme: Conceptualizing Technological Mimesis and Imitation Publics on the TikTok Platform', New Media \& Society, December 1-19. 


\section{Author}

Arran John Rees

fhajr@leeds.ac.uk

ORCID iD: http://orcid.org/0000-0001-7155-5335

URL: http://www.fine-art.leeds.ac.uk/people/arran-rees/

University of Leeds

UK

\section{Bio Statement}

Research Associate in the School of Communications and Media at Loughborough University and Doctoral Researcher at the School of Fine Art, History of Art and Cultural Studies at the University of Leeds. 